\title{
L'asse urbano dal Duomo a Ponte Vecchio a Firenze: sistemi di attività affini e commercio su suolo pubblico
}

\author{
Federico Cioli \\ Roberta Ferretti
}

Abstract

II contributo si focalizza nell'indagare il rapporto tra le attività commerciali a carattere storico e tradizionale e gli spazi urbani, con particolare attenzione al 'valore urbanistico' che questi negozi generano costituendo elementi di un sistema di relazioni ben determinate e consolidate e mette in evidenza la stretta interdipendenza tra attività economica e utilizzo del suolo pubblico. Le attività di censimento e documentazione fanno parte di un più ampio progetto di ricerca svolto a partire dal 2017 dal laboratorio congiunto HERE Lab dell'Università di Firenze e il Comune di Firenze. I recenti sviluppi della ricerca promossa dal Comune di Firenze, hanno richiesto l'approfondimento di una categoria spesso poco considerata all'interno dei sistemi di tutela dei centri storici, ovvero quella del commercio su suolo pubblico. II commercio su area pubblica, nelle sue diverse forme, riveste ancora oggi un ruolo importante: nei centri storici rappresenta un'attrattiva commerciale in grado di arricchire l'offerta del commercio tradizionale mentre nei centri minori e nelle periferie rappresenta un importante sostegno per la rete distributiva locale. I dati raccolti nel corso dei primi tre anni di progetto si sono rivelati una fonte di informazioni utile a comprendere i processi evolutivi della città nel tempo e le modificazioni più recenti consentendo un costante monitoraggio dei cambiamenti e delle chiusure di queste attività, soprattutto in periodo di pandemia, che in assenza di un'adeguata documentazione rischiano di scomparire senza lasciare traccia del loro passato.
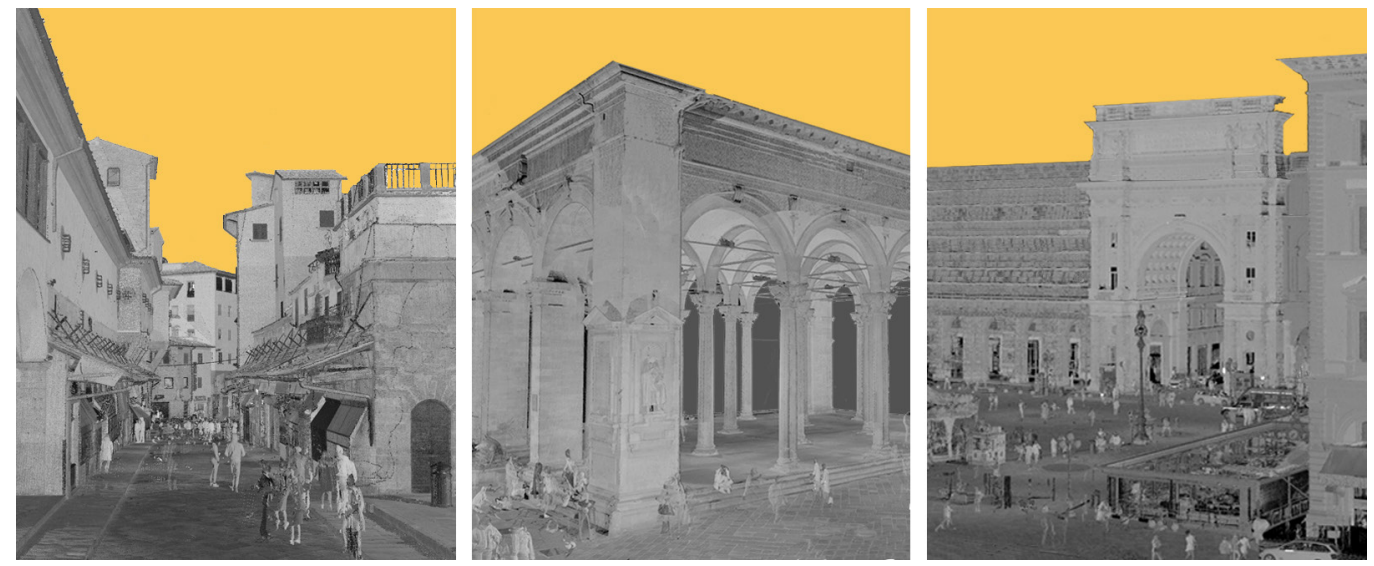


\section{Introduzione}

Il commercio è storicamente uno dei principali motori degli scambi culturali tra le città e i rispettivi territori, influenzando gli stili, il gusto e le abitudini delle popolazioni [ I ]. Nel tempo però, queste relazioni tra il negozio e il luogo pubblico, la strada o la piazza, è cambiato, creando dei sistemi complessi che sempre più trascendono il piano fisico del rapporto tra passante e vetrina, e tendono a entrare nel mondo "iperuranico" delle telecomunicazioni, dove gli scambi sono costanti e il prodotto perde il suo carattere locale e diventa globale. La città contemporanea si può schematicamente strutturare secondo una duplice spazialità: quella fisico-territoriale del quotidiano e delle relazioni sociali che viene vissuta nelle strade e nelle piazze, e quella sovralocale, virtuale o topologica dei flussi e delle reti [Fiorani 2005, p. I I]. Entrambe inseguono la domanda di consumo, di moda e di pubblico comportando cambiamenti che contribuiscono talvolta a indebolirne nel tempo l'identità storica [Codeluppi, Ferraresi 2007, p. I3.].

Mutano dunque costantemente e a velocità sempre crescente i modi e le forme del manifestarsi della vita pubblica e privata, del commercio e delle attività produttive, i mezzi di trasporto e gli elementi di arredo, il modo di relazionarsi tra le attività commerciali e il marciapiede e con loro anche i protagonisti che le percorrono. Questi processi configurano l'architettura degli spazi urbani come un fatto dinamico: le strade, le piazze e i palazzi costituiscono la costante che definisce la struttura della città, mentre le attività che vi si svolgono sono inevitabilmente soggette ai cambiamenti della vita sociale dei cittadini.

La strada accoglie la massima concentrazione della vita urbana: il piano terreno dei fabbricati è quello maggiormente soggetto al sempre più rapido evolversi delle 'mode"' e dei fenomeni contemporanei della globalizzazione e ha iniziato a perdere il suo valore locale specifico a vantaggio di una uniformità su scala mondiale. Questi cambiamenti sono stati fortemente condizionati dalla pandemia di COVIDI9, che ha comportato un predominio degli aspetti 'virtuali' della vita, trasformando il suolo pubblico in un contesto controllato. Nell'indagare questo rapporto tra la città e il commercio l'attenzione viene posta sulla città storica contemporanea al fine di comprendere il valore del commercio nel modo di vivere le strade e come esso sia parte integrante del patrimonio architettonico e culturale.

II contributo costituisce un approfondimento della tematica generale già affrontata in varie pubblicazioni [Bertocci, Cioli 20 I8; Bertocci, Cioli, Bordini 20I8] e si focalizza nell'indagare il rapporto tra le attività commerciali di carattere storico e tradizionale e gli spazi urbani, con particolare attenzione al "valore urbanistico" che questi negozi generano nel sistema di relazione con altri simili e mette in evidenza la stretta interdipendenza tra attività economica e suolo pubblico. Le attività di censimento e documentazione fanno parte di un più ampio progetto di ricerca svolto a partire dal 2017 dal laboratorio congiunto HERE Lab (Heritage and Research Lab) dell'Università di Firenze e il Comune di Firenze, sotto la responsabilità scientifica del prof. Stefano Bertocci. I dati raccolti nel corso dei primi tre anni di progetto si sono rivelati una fonte di informazioni utile a comprendere i processi evolutivi della città nel tempo e le modificazioni più recenti consentendo un costante monitoraggio dei cambiamenti e delle chiusure di queste attività che in assenza di un'adeguata documentazione rischiano di scomparire senza lasciare traccia del loro passato [2].
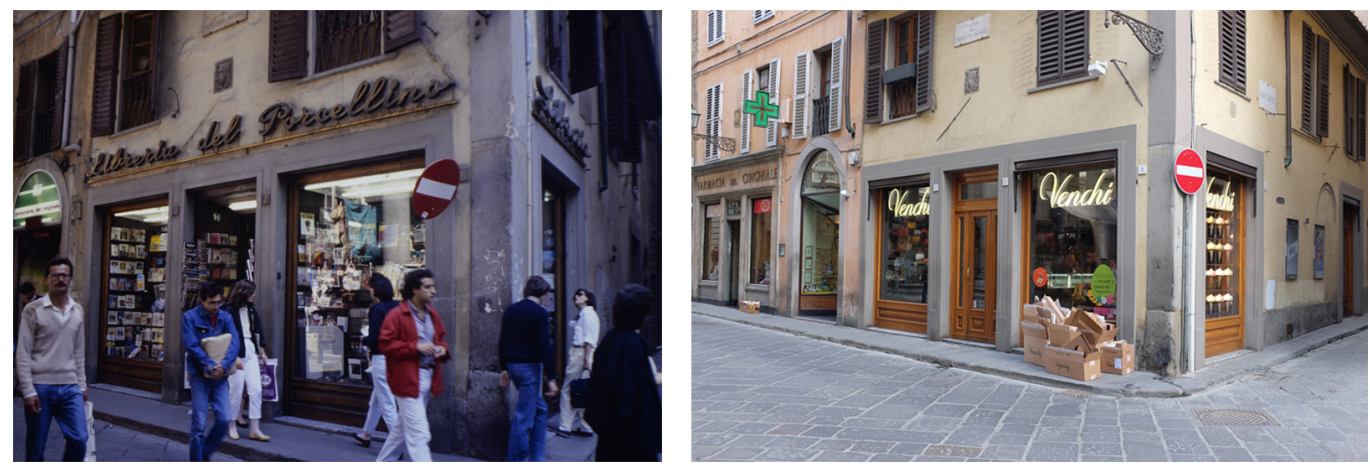
Sistemi di attività commerciali affini: Piazza della Repubblica, la Loggia del Mercato Nuovo e Ponte Vecchio

Il progetto di documentazione dei negozi storici e delle attività commerciali fiorentine ha richiesto lo sviluppo di un apposito sistema di schedatura e censimento, che è stato affiancato dall'acquisizione di fotografie e di video mirati a restituire l'immagine architettonica degli esercizi commerciali e i processi artigianali di lavorazione. Sono state inoltre condotte campagne di rilievo digitale su casi a campione, funzionali a comprendere e gestire il sistema di relazioni tra le attività, il fronte urbano e la loro influenza sull'immagine della città, nonché a porre le basi per uno studio sulle loro caratteristiche stilistiche e architettoniche. La finalità di questa indagine su scala urbana è quella di comprendere il legame che si instaura tra i negozi, le strade e le piazze cittadine, con particolare attenzione ai sistemi di attività affini, che si definiscono come raggruppamenti di esercizi commerciali accomunati dalla stessa categoria merceologica in determinati contesti. Nel 2020 è stata condotta una campagna di rilievo digitale integrato che ha riguardato una delle principali vie del centro storico, che parte da Piazza Duomo (compresa) e raggiunge i lungarni. Questo tragitto passa per alcuni dei più importanti luoghi del commercio fiorentino, caratterizzati proprio dalla presenza di questi sistemi: Piazza della Repubblica con i suoi caffè storici, la Loggia del Mercato Nuovo, uno dei principali raggruppamenti turistici del centro storico e Ponte Vecchio con le caratteristiche botteghe orafe. Questi tre luoghi, strettamente legati all'immagine della città di Firenze, sono fortemente condizionati dalle strategie di tutela adottate. Basti pensare che delle attività commerciali ancora presenti all'interno del tessuto urbano di Firenze, tra le poche che presentano un decreto di vincolo della Soprintendenza Archeologia Belle Arti e Paesaggio ci sono i caffè storici Paszkowski ( 1896) e Gilli (1733) in Piazza della Repubblica, insieme alle Giubbe Rosse (1896) a rischio di chiusura e recentemente vincolato nel 2019, in quanto rappresentano "una testimonianza significativa legata alla cultura fiorentina dei primi decenni del '900" [3]. Aperti in seguito al risanamento dell'area del Mercato Vecchio successivamente agli interventi per Firenze Capitale (| 865- | 87| ), questi caffè hanno contribuito a definire l'immagine della piazza e per questo vengono riconosciuti come elementi da tutelare. Questo approccio alla salvaguardia basato su un sistema vincolistico puntuale ha messo in evidenza la mancanza di una documentazione coerente e organica, rendendo necessario lo sviluppo di un progetto di ricerca esteso a tutto il territorio comunale con l'o-

Fig. 2. (a sinistra) Assonometria estratta dalla nuvola di punti: sono strutture mobili oggetto del censimento e i principali luoghi del commercio (Piazza della Repubblica, Mercato Nuovo e Ponte Vecchio) sull'asse urbano che unisce il Duomo a Ponte Vecchio; (a destra) Planimetria della nuvola di punti che vede l'unione del rilievo laser-scanner diVia Roma, realizzato con Rin $\mathrm{Ri}$, con 2020 , nel 2020, ell rilievo di via Calzaiuoli realizzato con uno Z+F 5006h ne 2016, attraverso punt topografici.

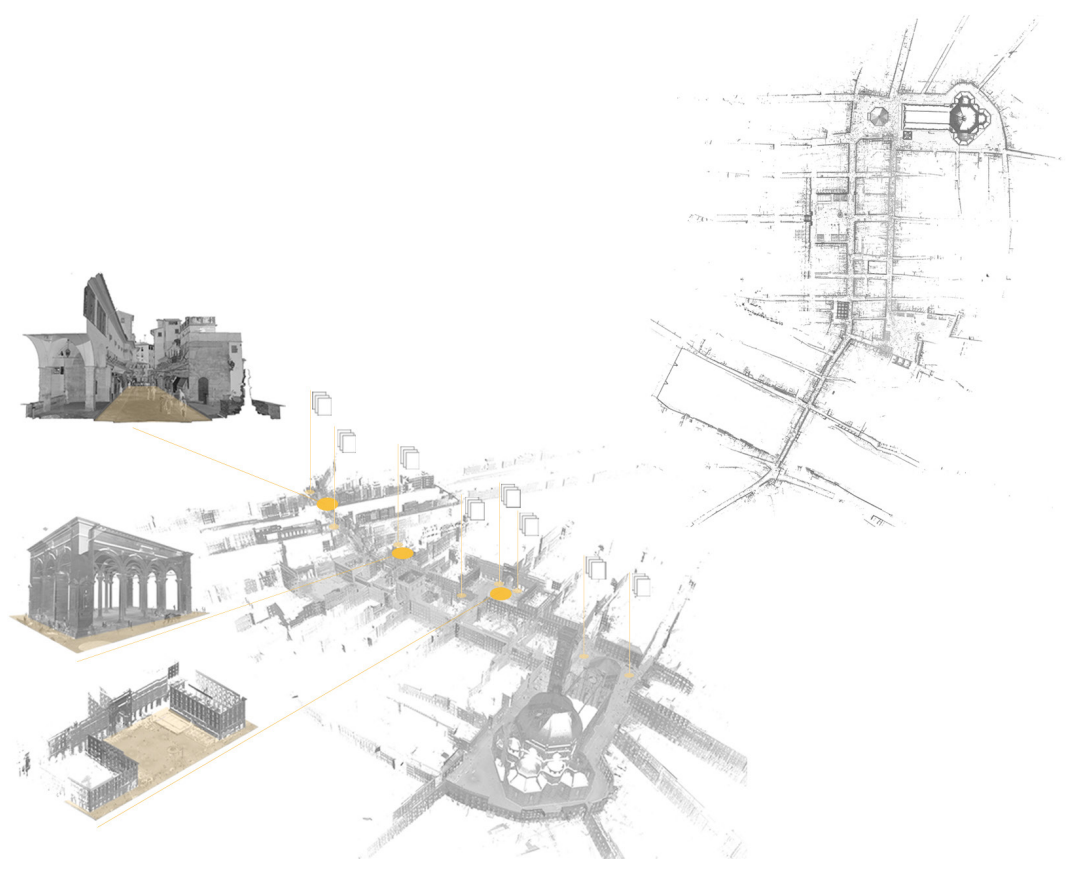

|49 | 
Fig. 3. (in basso) Sezione prospettica estratta rappresentante la Piazza del Mercato Nuovo.I rilievo è stato realizzato rilievo è stato realizzato nel 2020. Sono indicati nel 2020. Sono indicati il Lampredottaio del Porcellino (censito in occasione del progetto di documentazione de chioschi, le edicole e i fiorai su area pubblica de Comune di Firenze e facente parte delle Attività Storiche - Categoria C) la Farmacia del Cinghiale (censita in occasione de progetto di casione de prone dei negozi storici delle attività commercia fiorentine), (in alto) una fiorentine), (in alto) una Mercato Nuovo (studenti: Giulia Moscardini, Luigi Perrotta). biettivo di individuare i parametri di identificazione di un'attività commerciale di valenza culturale e di costituire un archivio digitale utile sia per la conoscenza che per il monitoraggio. I recenti sviluppi della ricerca hanno richiesto l'approfondimento di una categoria spesso poco considerata all'interno dei sistemi di tutela dei centri storici, ovvero quella del commercio su suolo pubblico. II Regolamento per la tutela e la valorizzazione delle attività economiche storiche e tradizionali fiorentine, approvato il 25 giugno 20 18, riconosce infatti tra le categorie di attività da tutelare quella degli "Ambulanti Storici", ovvero quelle attività che operano su suolo pubblico, portando avanti una tradizione profondamente legata alla realtà sociale del centro storico di Firenze.

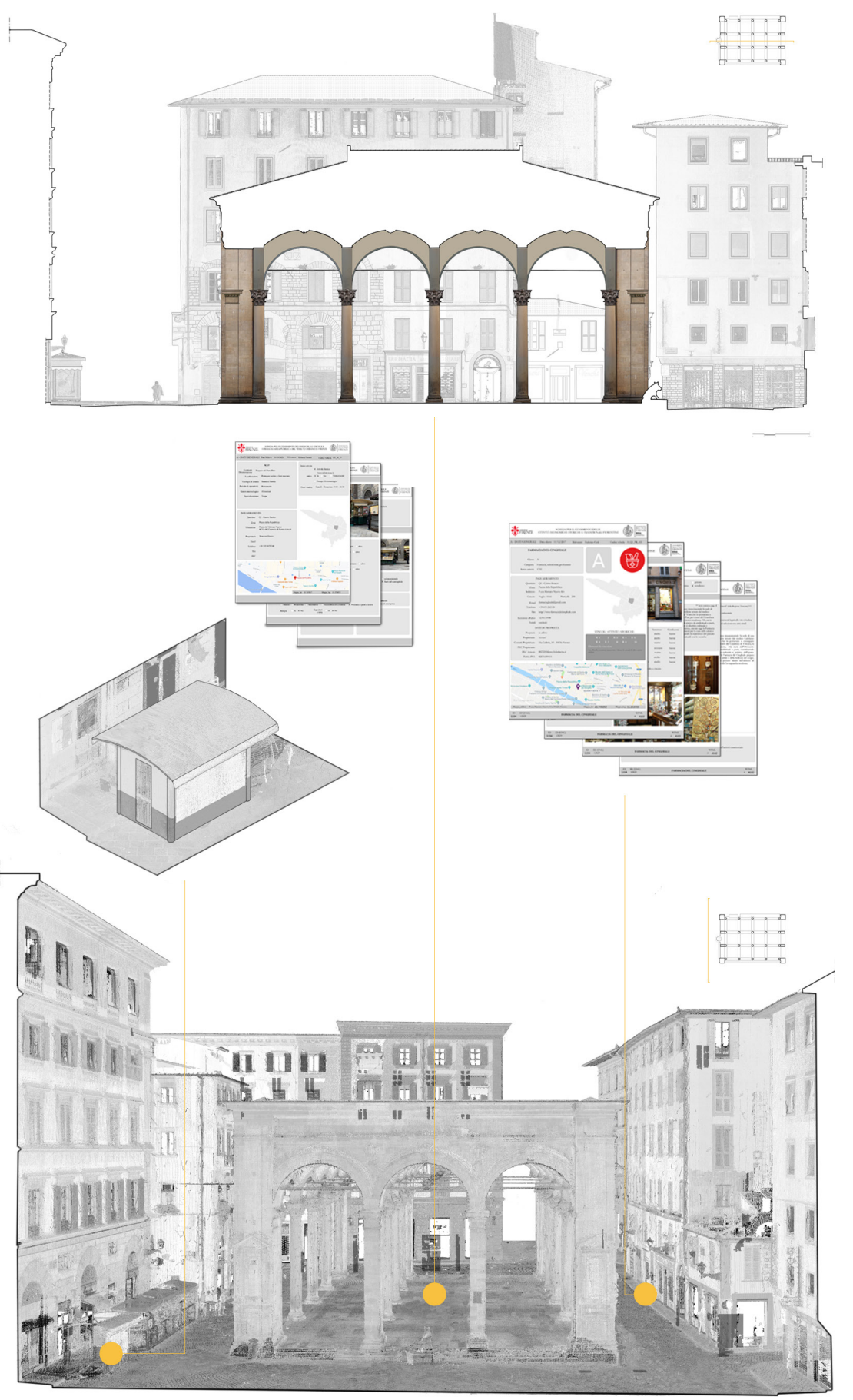




\section{Il progetto di documentazione dei chioschi, le edicole e i fiorai su area pubblica del Co- mune di Firenze}

Nel corso della storia le trasformazioni economiche, sociali e normative, le innovazioni tecnologiche e di viabilità e le scoperte produttive hanno contribuito a modificare sensibilmente le caratteristiche del commercio su area pubblica. II commercio su strada ha origini antichissime tanto da poter essere considerato una delle prime professioni esercitate dall'uomo non solo per necessità, ma anche con lo scopo di trarne un vantaggio economico utilizzando capacità e attitudine personale. La figura del venditore ambulante è riconducibile a una figura errante e solitaria che, nel corso della storia, si è fatta tramite di connessioni tra popoli diversi favorendo lo scambio non solo di prodotti ma anche di informazioni, linguaggi e tradizioni [4].

II commercio su area pubblica, nelle sue diverse forme, riveste ancora oggi un ruolo importante: nei centri storici rappresenta un'attrattiva commerciale in grado di arricchire l'offerta del commercio tradizionale mentre nei centri minori e nelle periferie rappresenta un importante sostegno per la rete distributiva locale. I fattori che hanno permesso al commercio ambulante di sopravvivere nonostante la diffusione della grande distribuzione sono strettamente legati alle sue caratteristiche, esso infatti garantisce un'offerta commerciale varia e diversificata, normalmente a prezzi più vantaggiosi rispetto a quelli di altre categorie distributive, è in grado di soddisfare un'ampia fetta di clientela e il contatto diretto con la merce e la possibilità di saggiarne la qualità da parte del cliente rappresenta senz'altro il maggior vantaggio di questo canale distributivo rispetto agli altri. L'ambulantato, inoltre, ha sempre svolto e svolge tuttora un importante ruolo socioculturale basato principalmente sul rapporto diretto tra commerciante e compratore, arricchito dalla sua funzione di catalizzatore dello spazio urbano. II commercio su area pubblica trae, inoltre, un indubbio beneficio dal fatto di avere come sede privilegiata il mercato dove un'ampia offerta di prodotti si trova in uno spazio relativamente contenuto.

L'evoluzione del commercio su area pubblica in Toscana e, più in generale, in Italia lo ha reso un fenomeno del tutto particolare rispetto a quello degli altri paesi europei [5]. A Firenze, ad esempio, fondini, il cui nome fa riferimento alla particolare posizione che questi banchi occupavano in fondo al mercato, e cassettai, che prendono il loro nome dal contenitore a forma di cassetta utilizzato per esporre e vendere la merce, rappresentano una vera e propria tradizione tra gli ambulanti del centro storico. Sui loro banchi sono in vendita prodotti dell'artigianato locale, souvenir, guide turistiche, cartoline e libri di vario genere. Questi, insieme ad altre attività storiche operanti su strada e nei principali mercati e raggruppamenti

Fig. 4. (sinistra) Giorgio Vasari: II modello per la loggia del Mercato Nuovo, Palazzo Vecchio, camera di Cosimo I, particolare del tondo con Cosimo e gli artisti a corte; (destra) Battista del Tasso: Schizzo delle edicole del Mercato Nuovo (GDSU 4 I06 Av) Nuovo (GDSU 4l06 Av) (da: Battilotti D., Belluzzi A.
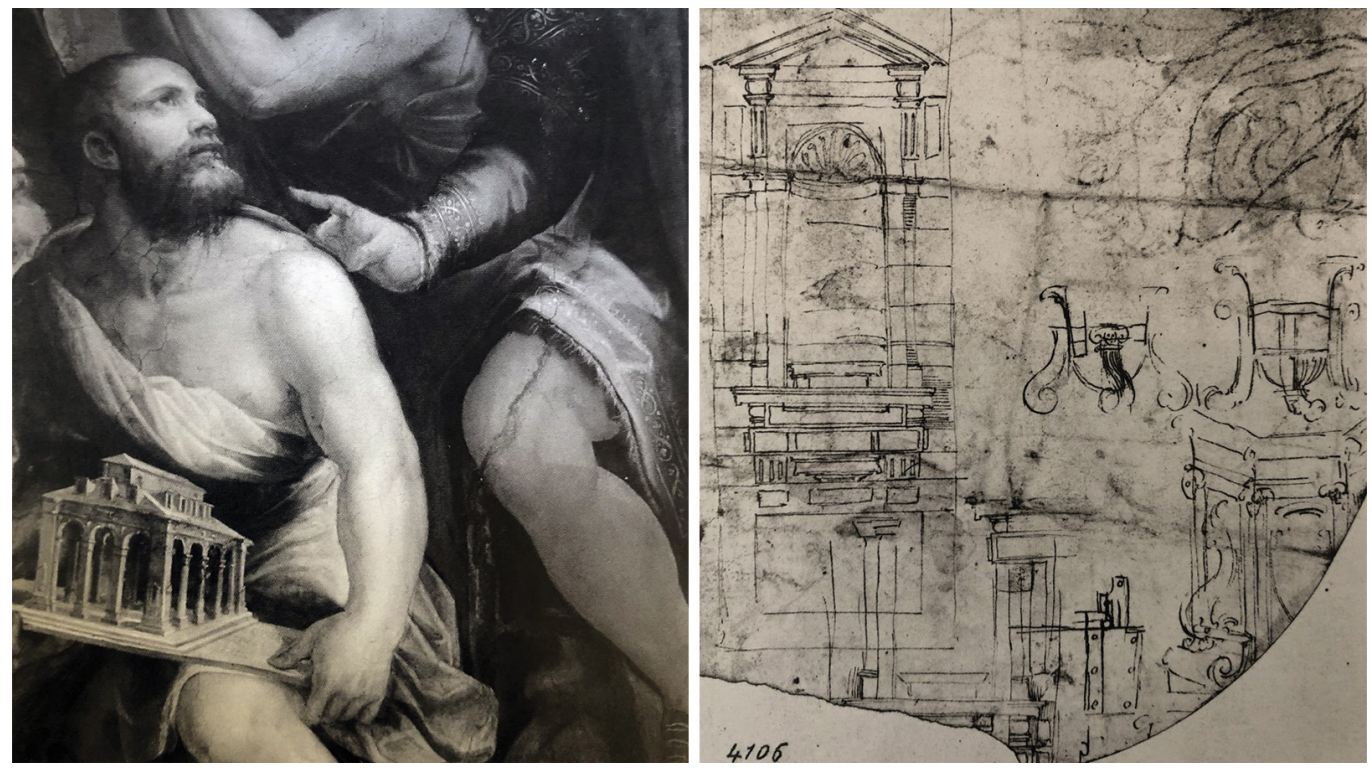
Fig. 5. Elaborato

rappresentante una

porzione di Ponte Vecchio:

ezione longitudinale

studenti: Serena Livian

Claudia Logi, Giacomo

Morelli, Lorenzo Tognoni,

Gilda Mugnaini, Tommaso

Olianas).

Fig. 6. Elaborato

rappresentante una

porzione di Ponte Vecchio:

sezione longitudinale

studenti: Serena Liviani,

Cludenti: Serena Liviani,

Cladia Logi, Giacomo

Morelli)

Fig. 7. Elaborato

rappresentante Ponte

ecchio: sezioni trasversal

(studenti: Serena Livian

Claudia Logi, Giacomo

Morelli).
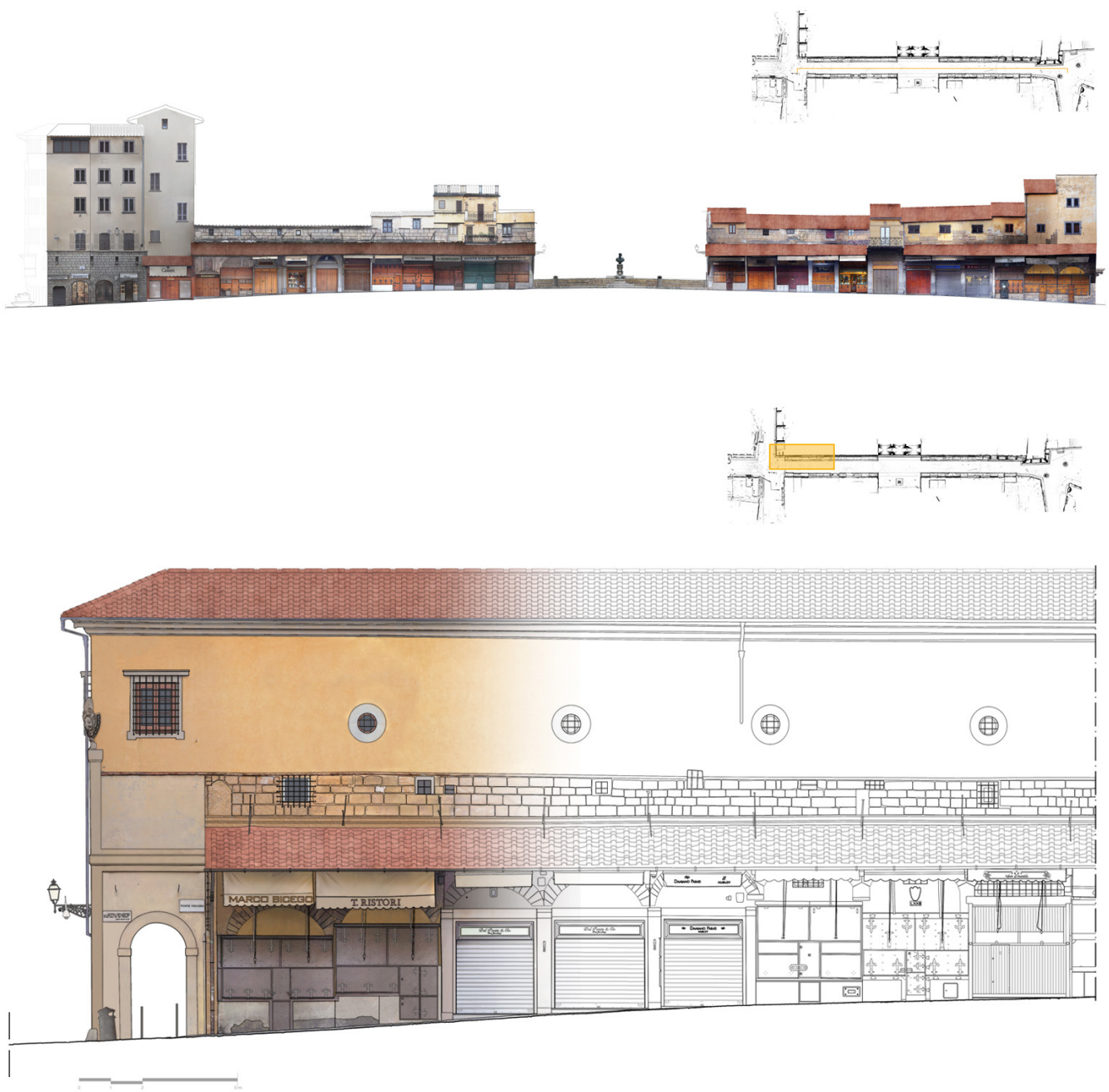

$H=$
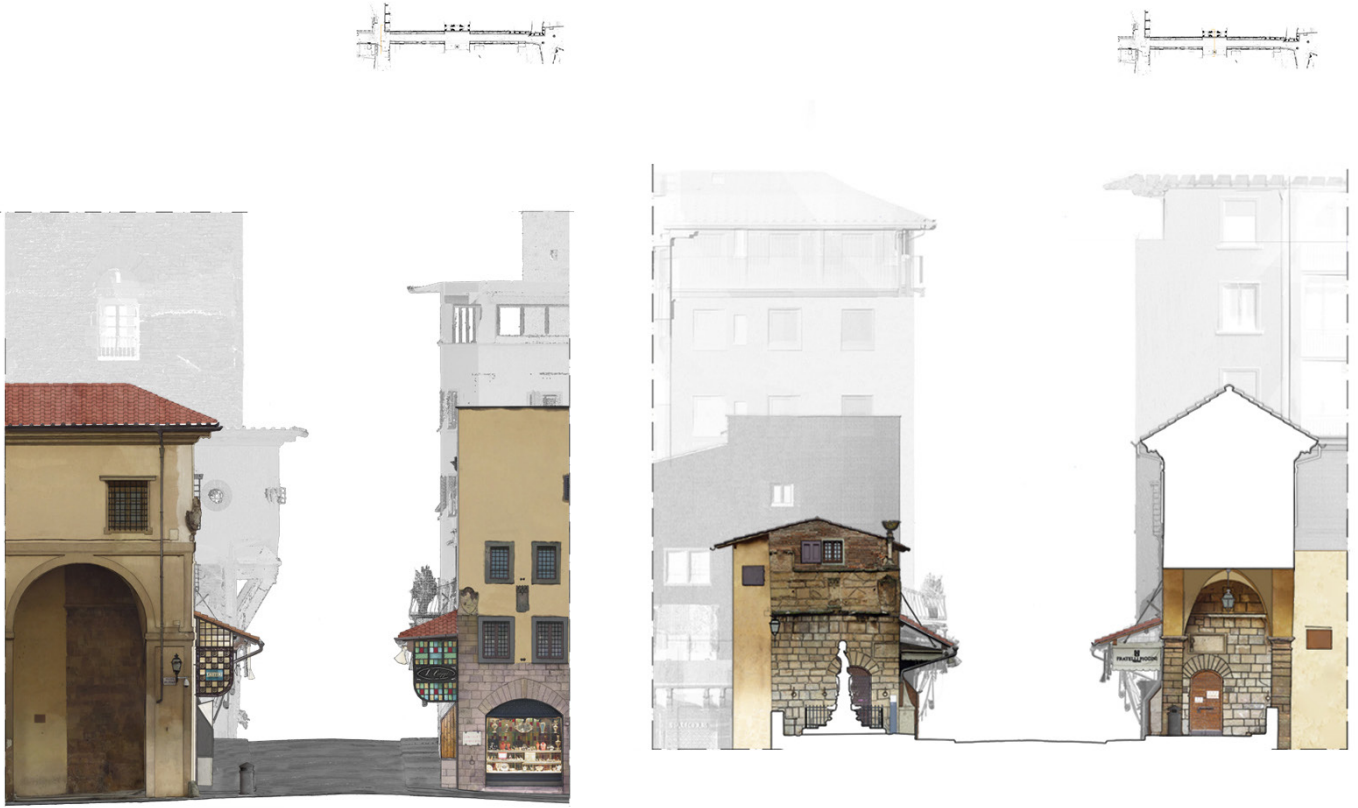
turistici della città, sono riconosciuti tra le Attività Economiche Storiche e Tradizionali Fiorentine appartenenti alla categoria C - "Ambulanti Storici".

Il progetto di documentazione dei chioschi, le edicole e i fiorai su area pubblica del Comune di Firenze ha riguardato la strutturazione di un sistema di schedatura che permettesse di prendere in considerazione efficacemente tutte le caratteristiche di queste particolari attività commerciali, il controllo e l'aggiornamento dei dati contenuti nel regolamento per la disciplina dell'attività commerciale su area pubblica e lo svolgimento di una campagna fotografica per la documentazione dello stato di fatto delle strutture.

La scheda è stata strutturata sulla base delle informazioni contenute allinterno del Regolamento per la disciplina dell'attività su area pubblica (2008) ed è stata successivamente arricchita con elementi emersi durante le operazioni di censimento.

Può essere divisa in tre sezioni:

A) Dati generali: nella prima sezione della scheda vengono forniti i dati di inquadramento, quindi tutte le informazioni relative alla proprietà, la zona commerciale e la posizione all'interno della città o del mercato. Proprio per definire con precisione l'ubicazione vengono inserite le coordinate, che in questo caso assumono un'importanza particolare in quanto la posizione di tali strutture non è definibile tramite un indirizzo canonico (possono trovarsi all'incrocio tra due strade, all'interno di un giardino).

In questa parte della scheda viene inoltre indicato se si tratta di una struttura mobile o di un chiosco permanente, con riferimento anche al genere merceologico.

B) Descrizione della struttura: la seconda sezione della scheda è dedicata alla descrizione della struttura che ospita l'attività commerciale, essa viene descritta dal punto di vista visivo fornendo informazioni relative, ad esempio, alla dimensione, al materiale e al colore e viene analizzata dal punto di vista qualitativo valutando lo stato di conservazione della struttura e la presenza di elementi di interesse, come opere di street art.

C) Rapporto con il contesto: la sezione conclusiva della scheda analizza l'attività commerciale dal punto di vista del rapporto con il contesto non solo urbano, indicando ad esempio la tipologia di strada in cui essa è collocata, ma anche sociale. Alcune delle attività commerciali prese in esame sono, infatti, di riferimento per i residenti del quartiere, rappresentano importanti luoghi di incontro e aggregazione sociale, oppure si trovano nei pressi di edifici di alto interesse storico, artistico o culturale.

Fig. 8. Fotografie eseguite durante la campagna fotografica per la documentazione dei chioschi, le edicole e i fiorai su area pubblica de Comune di Firenze.
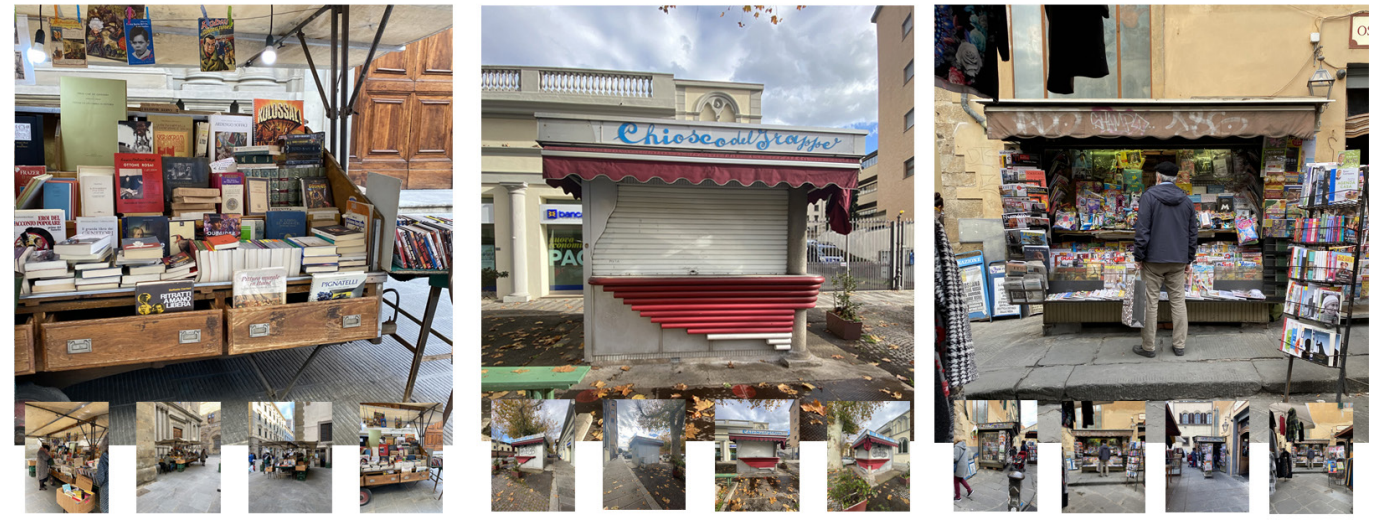

\section{Analisi dei risultati}

Sono state censite 207 attività commerciali su tutto il tessuto urbano della città di Firenze, di cui I 47 chioschi e 6 I strutture mobili. La maggior parte di esse è situata all'interno del perimetro del centro storico e di queste poco meno della metà si trova all'interno delle zone commerciali Duomo e Piazza della Repubblica. L'analisi dei risultati ottenuti ha evidenziato come circa un quarto delle attività presenti negli elenchi allegati al Regolamento per la disciplina dell'attività su area pubblica (2008) risultano attualmente non presenti o non attive. 
Fig. 9. Scheda tipo strutturata durante il progetto di documentazione de fiorai su area pubblica del Comune di Firenze.
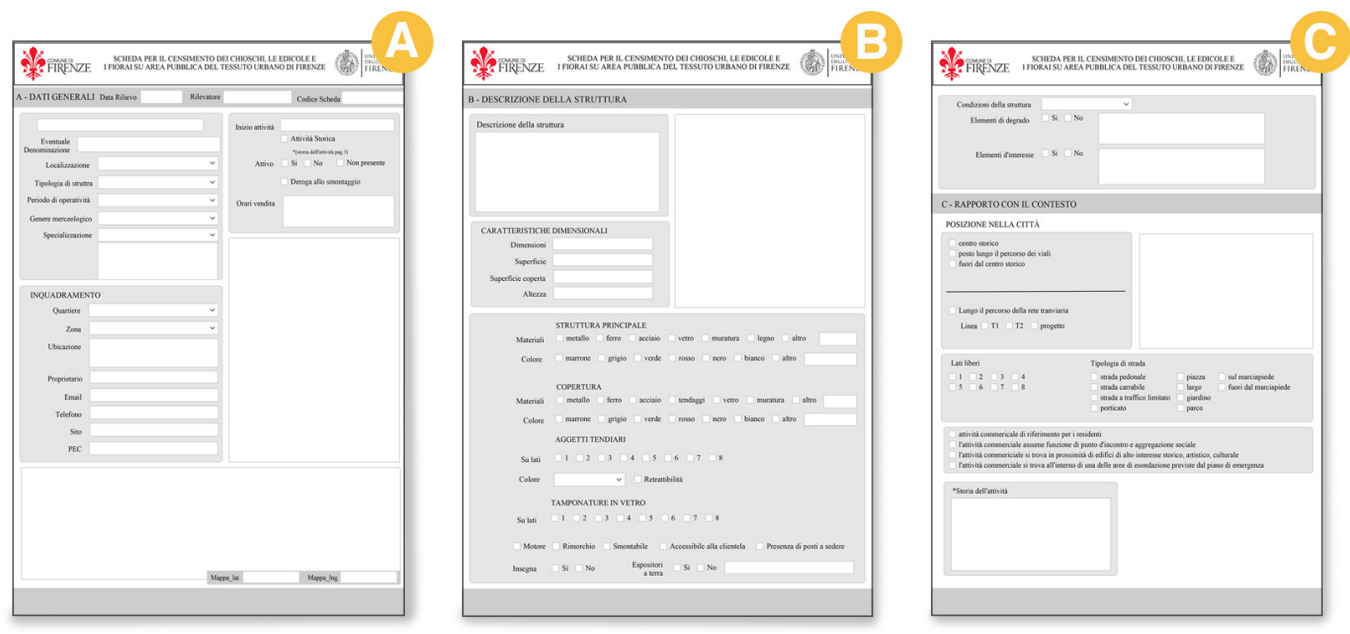

L'analisi dei generi merceologici ha, invece, evidenziato come il commercio su strada continui a mantenere la sua tradizionale caratteristica di veicolo d'informazioni con la presenza delle edicole, la sua componente sociale con i chioschi dedicati alla somministrazione e a rappresentare l'identità della città permettendo la distribuzione di prodotti della tradizione come il lampredotto o articoli di artigianato locale.

II commercio nelle sue diverse forme è, quindi, parte integrante della struttura urbana della città: ne caratterizza l'aspetto e contribuisce in modo sostanziale alla vitalità dei centri. È proprio questa dinamicità a renderlo un settore particolarmente sensibile ai cambiamenti economici e sociali. II censimento e la documentazione dei negozi storici e delle attività commerciali fiorentine, dei chioschi, le edicole e i fiorai su area pubblica del Comune di Firenze attraverso lo studio anche di un caso campione relativo al rilievo dell'asse urbano che unisce il Duomo a Ponte Vecchio hanno permesso di ottenere un quadro complessivo delle relazioni che intercorrono non solo tra le diverse attività economiche ma anche tra queste e il contesto urbano in cui sono inserite, evidenziando il ruolo fondamentale che la strada, luogo pubblico per eccellenza, riveste nella definizione di questi legami. Il confronto con i dati di partenza ha inoltre evidenziato quanto queste attività siano in continua evoluzione e quindi quanto le costanti attività di documentazione e monitoraggio siano importanti per tenere traccia della loro trasformazione.

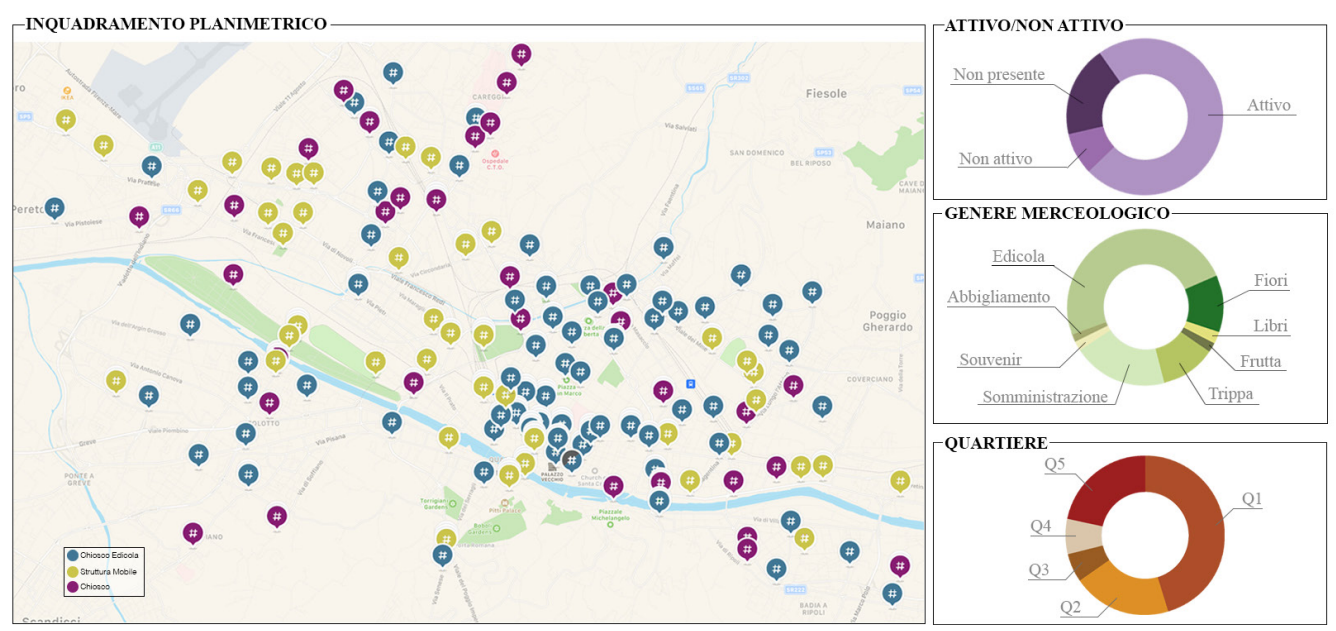




\section{Note}

[I] Si deve a Federico Cioli la redazione dei paragrafi I e 2. Si deve a Roberta Ferretti la redazione dei paragrafi 3 e 4.

[2] Nei centri storici sono ancora presenti numerose insegne, spesso tutelate dalle Soprintendenze locali, appartenenti ad attività chiuse da tempo. Esse rimangono come testimonianze mute di un passato commerciale e produttivo che, prive di qualsiasi apparato informativo, si configurano principalmente come mero elemento di arredo urbano.

[3] Decreto attuale di tutela del Ministero sul Caffè Paszkowski del 24/10/1991.

[4] Emblematico è il caso dei librai pontremolesi che, durante l'800, si trasformarono in veri e propri "corrieri d'informazioni' [Mazzocchi 200।, p. 28].

[5] Legge regionale n. 10 del 4 febbraio 2003 Norme per la disciplina del commercio su aree pubbliche.

\section{Riferimenti bibliografici}

Balzanetti Steiner G. (200I). Firenze disegnata le strade da porta a porta nella successione delle mura urbane (Architettura e arte in Toscana 10). Firenze: Alinea.

Bertocci S., Cioli F. (20/8). La documentazione delle attività commerciali storiche del centro di Firenze. In R. Salerno (a cura di). Rappresentazione materiale/immateriale - Drawing as (in) tangible. 40 Convegno UID. Milano, I3- I5 settembre 20 I8, pp. 94 I-48. Roma: Gangemi Editore.

Bertocci S., Cioli F., Bordini E. (2018).Virtual models for the valorisation and promotion of the business heritage in the historic centre of Florence. In Disegnarecon:Advanced Technologies for Historical Cities Visualization, vol. I I, N. 2I, pp. 2. I-2. I9.

Betti S., Porto C. M. (2019). II commercio ambulante nella città contemporanea marchigiana. Analisi e prospettive di sviluppo. In AGEI - Geotema, n. 38, pp. I 8-29.

Bini M. (20।8). Le trasformazioni dell'immagine urbana: il sistema delle "botteghe". In P. Puma (a cura di). Firenze, la trasformazione del centro antico, pp. 62-72. Firenze: Edifir Edizioni Firenze.

Codeluppi V., Ferraresi M. (2007). La moda e la città (Studi economici e sociali Carocci 3). Roma: Carocci.

Fiorani E. (2005). I panorami del contemporaneo. Milano: Lupetti.

Job A., Laureati L., Ronchetta C., (1985). Botteghe e negozi a Torino / 8/ 5-1925. Immagine del commercio fra architettura e decorazione. Torino: Allemandi.

Mazzocchi A. (200 I). I pellegrini del commercio - Il commercio ambulante: economia, cultura e società. Trento: II Margine.

Osello A., Coppo S., Coppo D. (2007). Il Disegno di Luoghi e Mercati in Piemonte. Torino: Allemandi.

Pugnetti G. (1978). I Venditori ambulanti nel cammino della civiltà. Roma: Istituto Editoriale Regioni Italiane.

Romby G. C. (1989). Le forme e i luoghi del vendere e del comprare. In Proceedings of II negozio nel centro storico: nascita, vita, prospettive. Convegno nazionale, Lucca, Villa Bottini, I5 gennaio 1989.

Senatore L.J. (20I3). La rappresentazione nello spazio commerciale. Storia, modelli, tendenze. Roma:Aracne.

\section{Autori}

Federico Cioli, Università di Firenze, federico.cioli@unifi.it

Roberta Ferretti, Università di Firenze, roberta.ferretti@unifi.it

Per citare questo capitolo: Cioli Federico, Ferretti Roberta (2021). L'asse urbano dal Duomo a Ponte Vecchio a Firenze: sistemi di attività affini e commercio su suolo pubblico/The urban axis from Duomo to Ponte Vecchio in Florence: commercial activities systems and street trading. In Arena A. Arena M. Mediati D. Raffa P. (a cura di). Connettere. Un disegno per annodare e tessere Linguaggi Distanze Tecnologie. Atti del $42^{\circ}$ Convegno Internazionale dei Docenti delle Discipline della Rappresentazione/Connecting. Drawing for weaving relationship. Languages Distances Technologies. Proceedings of the $42^{\text {th }}$ International Conference of Representation Disciplines Teachers. Milano: FrancoAngeli, pp. $1489-1506$. 


\title{
The Urban Axis from Duomo to Ponte Vecchio in Florence: Commercial Activities Systems and Street Trading
}

\author{
Federico Cioli \\ Roberta Ferretti
}

Abstract

This paper is focused on investigating the relationship between historical and traditional shops and urban spaces, with particular attention to the 'urban value' which these shops generate by constituting elements of a system of well-defined and well-established relations, and highlights the close interdependence between economic activity and public area use. The census and documentation activities are part of a wider research project carried out since 2017 by the joint laboratory HERE Lab of the University of Florence and the Municipality of Florence. Recent developments in the research have required the deepening of a category often little considered within the systems of protection of the historic centers: the commerce on public area.

The commerce on public area still plays an important role: it represents a commercial attraction able to enrich the offer of the traditional commerce in the historical centers, and at the same time in the smaller centers and in the suburbs it is an important support for the local distribution network. The data collected during the first three years of the project have been a source of information useful to understand the evolutionary process of the city and the most recent changes. This data makes possible constant monitoring of changes and closures of these activities. Without adequate documentation, these shops risk disappearing without leaving a trace, especially in a time of pandemic.

Keywords

historical shops, UNESCO heritage, census, digital survey, intangible heritage.

Left: point cloud of Ponte Vecchio; center: an image extracted from the points of the Piazza del Mercato Nuovo; right: an image extracted from the point extracted from the por
cloud of Piazza della Repubblica.

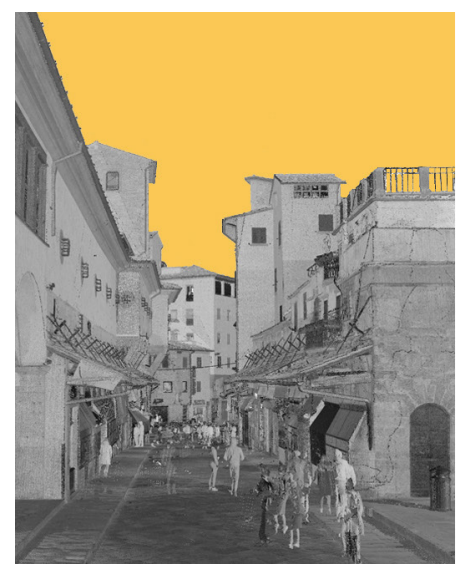

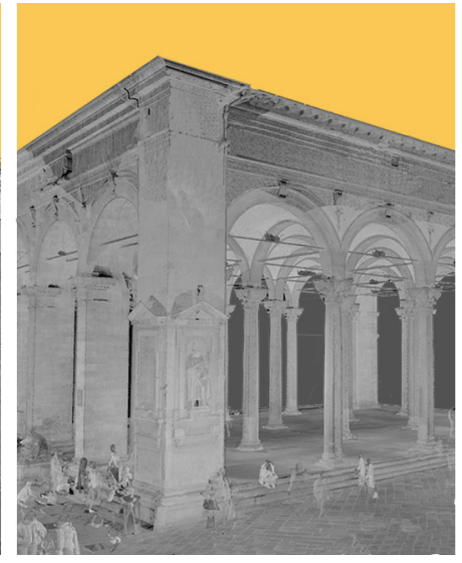

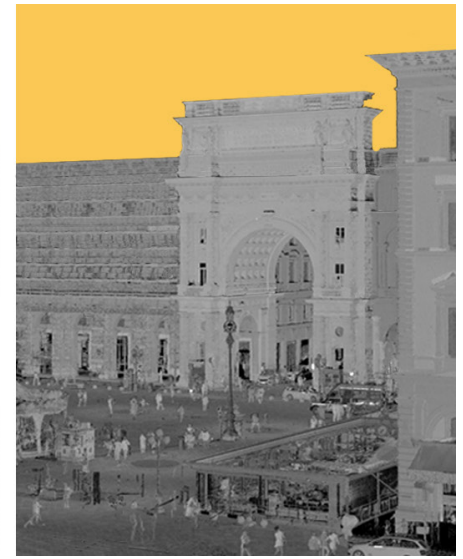




\section{Introduction}

Commerce has historically been one of the main drivers of cultural exchanges between cities and their respective territories, influencing the styles, tastes and habits of the population [I]. Over time this relationship between the store and the public place, the street or the square, has changed, creating complex systems that increasingly transcend the physical plane of the relationship between the passer-by and the showcase. It starts to enter the 'hyperuranic' world of telecommunications, where exchanges are constant and the product loses its local character and becomes global.

The contemporary city can be structured according to a double spatiality: the physical-territorial one of daily life and social relation that is lived in the streets and squares, and the supra-local, virtual or typological one of flows and networks [Fiorani 2005, p. I I]. Both pursue the demand for consumption leading to changes that sometimes contribute to weakening their historical identity [Codeluppi, Ferraresi 2007, p. I3]. The ways and forms of the manifestation of public and private life, of commerce and productive activities, of the mode of transport and furnishing elements, are changing constantly and at increasing speed. These processes constitute the architecture of urban spaces as a dynamic fact: streets, squares, and palaces are constants that define the structure of the city, while the activities that take place in these spaces are subject to changes in the social life of citizens. In the street, there is the maximum concentration of urban life: the ground floor of the buildings is the most subject to the increasingly rapid evolution of "fashions" and contemporary phenomena of globalization and has begun to lose its specific local value for the benefit of global uniformity. These changes have been strongly influenced by the pandemic of COVIDI9, which involved a predominance of 'virtual' aspects of life, transforming public soil into a controlled context. In investigating the relationship between the city and commerce, the attention is placed on the contemporary historical city to understand the value of trade in the way of living the streets and how it is an integral part of the architectural and cultural heritage. The paper constitutes a deepening of a general theme already raised in various publications [Bertocci, Cioli 20 I8; Bertocci, Cioli, Bordini 2018 ] and focuses on investigating the relationship between historical and traditional shops and urban spaces, with particular attention to the 'urban value' that these shops generate in the system of relationship with other similar places and highlights the close interdependence between economic activity and public space. The census and documentation activities are part of a wider research project carried out since 2017 by the joint laboratory HERE Lab (Heritage and Research Lab) of the University of Florence and the Municipality of Florence, under the scientific responsibility of Prof. Stefano Bertocci. The data collected during the first three years of the project have been a source of information useful to understand the evolutionary process of the city and the most recent changes. This data makes possible constant monitoring of changes and closures of these activities. Without adequate documentation these shops risk disappearing without leaving a trace, especially in a time of pandemic [2].
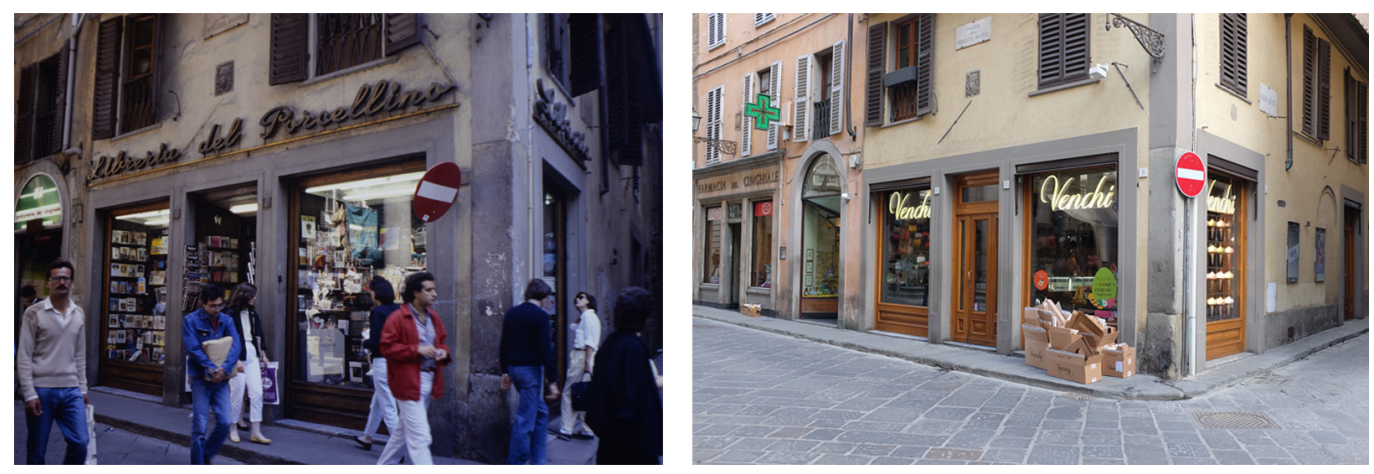


\section{Systems of related commercial activities: Piazza della Repubblica, Loggia del Mercato Nuovo and Ponte Vecchio}

The project of documentation of historical shops and commercial activities in Florence required the development of a special system of census, which was flanked by the acquisition of photographs and videos aimed at restoring the architectural image of business and craft process. Also, digital survey campaigns were carried out on sample cases, designed to understand and manage the system of relations between activities, the urban front and their influence on the image of the city, and to study their stylistic and architectural characteristics. The purpose of this survey at the urban scale is to understand the relationship between the shops, the streets and the city squares, with particular attention to systems of related activities which are defined as groupings of shops that share the same category of goods in certain contexts. In 2020, was conducted an integrated digital survey campaign that involved one of the main streets of the historic center, which starts from Piazza Duomo (included) and reaches the riverside. This path involves some of the most important places of Florentine commerce, characterized by the presence of these systems of related activities: Piazza della Repubblica with its historic cafes, the Loggia del Mercato Nuovo, one of the main tourist groupings of the old town and Ponte Vecchio with the characteristics goldsmith shops. These three places, closely linked to the image of the city of Florence, are strongly conditioned by the protection strategies adopted by the Municipality. Suffice it to say that, of the commercial activities still present within the urban fabric of Florence, among the few that present a decree of the Soprintendenza Archeologia Belle Arti e Paesaggio there are the historical cafes Paszkowski ( 1 896) and Gilli (1733) in Piazza della Reubblica, together with the Giubbe Rosse (1896) at risk of closure and listed in 2019, as they represent "a significant testimony linked to the Florentine culture of the first decades of the "900". These cafes have been opened after the restoration of the Mercato Vecchio area after the intervention for Firenze Capitale $(|865-| 87 \mid)$. These shops have helped to define the image of the square and for this they are recognized as elements to be protected. This approach to conservation based on a precise constraint system has highlighted the lack of coherent and organic documentation, making necessary the development of a research project extended to the entire municipal area to identify the parameters of identification of the cultural value of the shops and to create a digital archive useful for both knowledge and monitoring. The recent developments in the research have required the deepening of a category often little considered within the

Fig. 2. (left) Point cloud: axonometry of the urban axis that joins Duomo square to Ponte Vecchio in which are indicated the kiosks and the mobile structures which have been counted and the main places of commerce (Piazza della Repubblica, Mercato Nuovo e Ponte Vecchio); (right) plan of the point cloud result of the merger of the laser scanner survey of $V i a$ Roma made with a Rieg VZ-400i in 2020 and Survey of Via Calzanoli survey of via Calzaluoli in 2016 through topoin 2016, through topographical points.

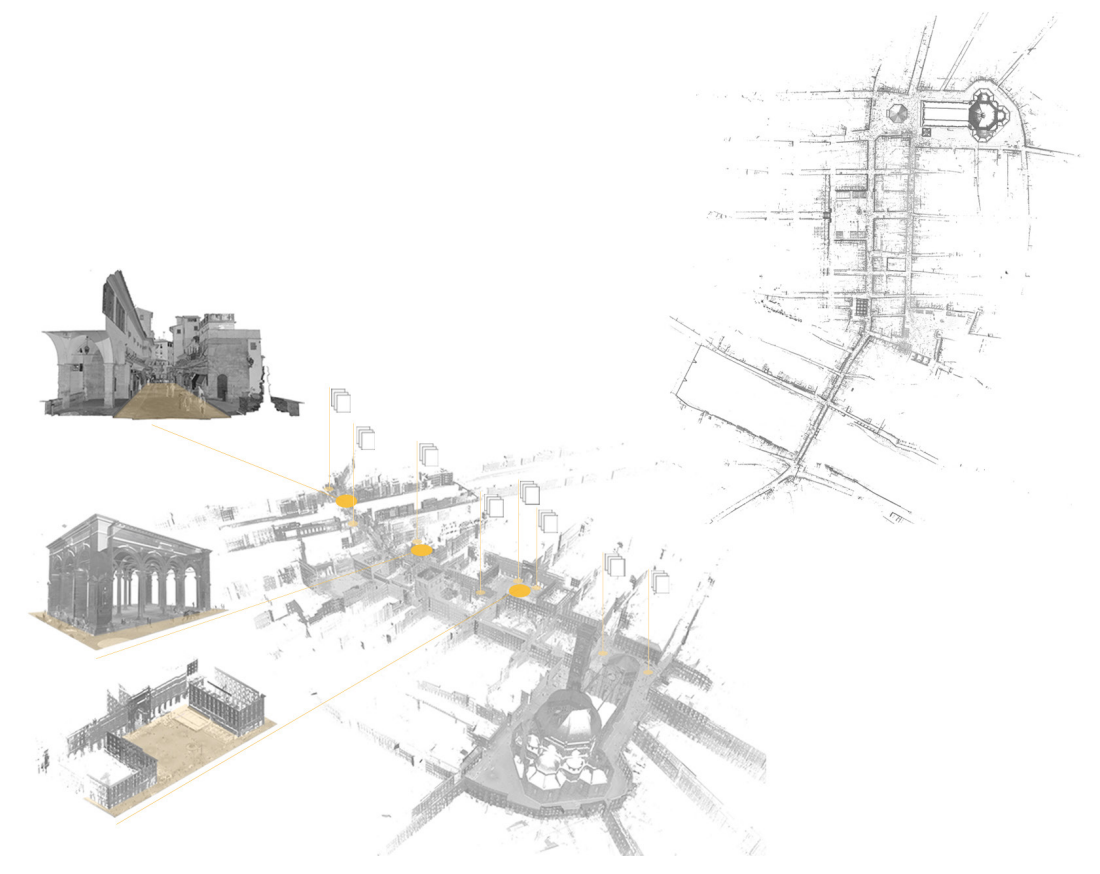


systems of protection of the historic centers: the trade on public area. The Regolamento per la tutela e la valorizzazione delle attività economiche storiche e tradizionali fiorentine, approved on June 25 of 2018 recongnizes among the categories of activities to be protected the "historical street vendor", which are those activities that operate in public area, carrying on a tradition deeply linked to the social reality of the historic center of Florence.

Fig. 3. A section extracted from the point cloud representing the Piazza survey was made with a Faro Focus M70 in 2020 Are indicated the Lampredottaio del Porcellino and the Farmacia del Cinghiale (at the top) a Cinghiale. (at the top) a secton of Plazza del Mercato Nuovo (students: Giulia Moscardini, Luigi Perrotta).
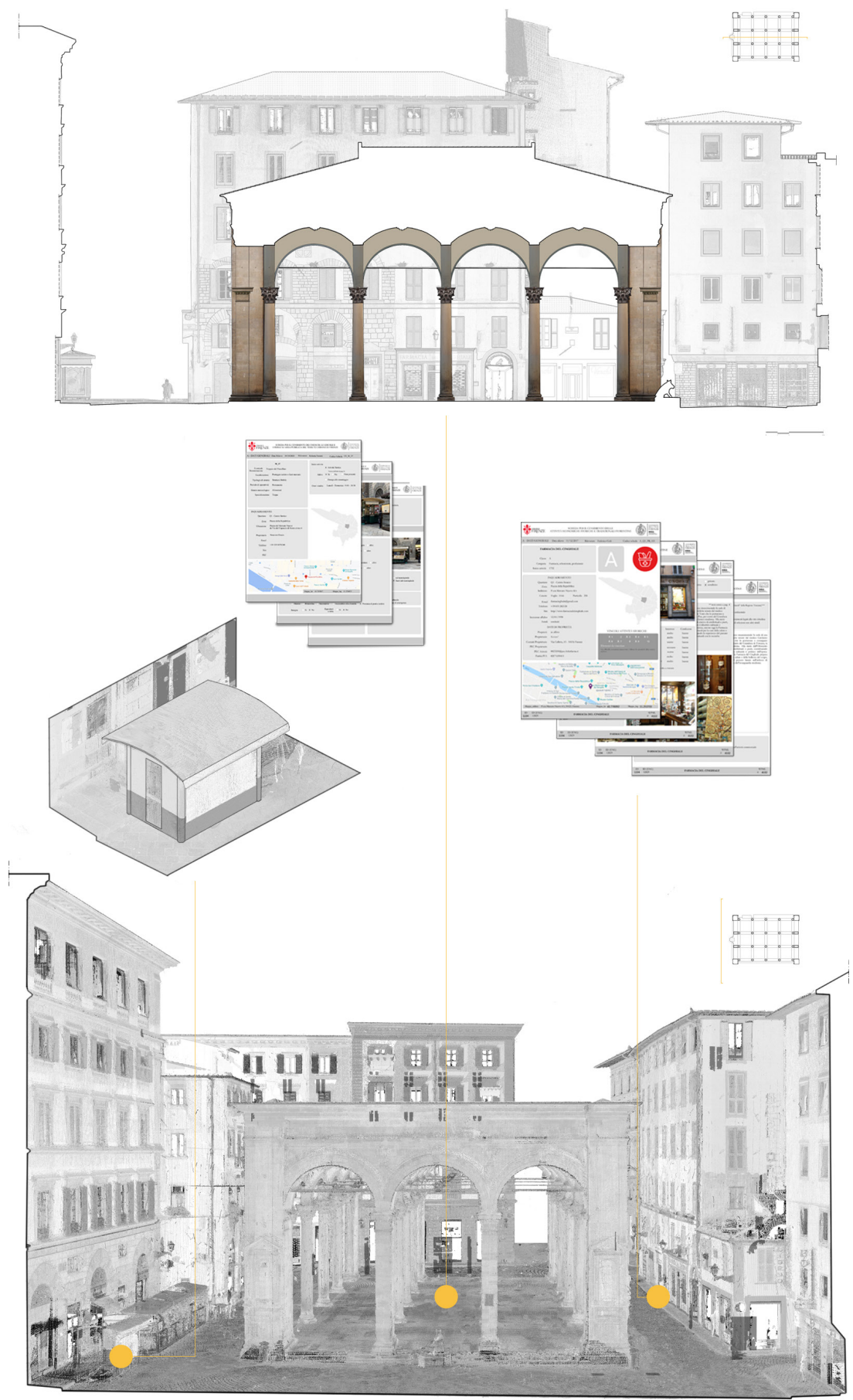


\section{Progetto di documentazione dei chioschi, le edicole e i fiorai su area pubblica del Comune di Firenze}

During history, economic, social, and regulatory transformation, technological and traffic innovations and productive discoveries have helped to significantly change the characteristics of trade on public areas. The road trade has very ancient origins so that can be considered one of the first professions exercised by man not only for necessity but also to draw an economic advantage from it, using personal skills and aptitude. The figure of the street vendor is attributable to a wandering and solitary figure that, throughout history, has made possible the connections between different people, promoting the exchange not only of products but also of information, languages, and traditions [4].

The factors which have permitted itinerant commerce to survive despite the spread of largescale distribution are closely linked to its characteristics: it guarantees a varied and diversified commercial offer, normally at more advantageous prices than other distribution categories, it can satisfy a large segment of customers and the direct contact with the goods and the opportunity for the customer to test the quality is certainly the greatest advantage of this distribution channel compared to others. Moreover, commerce on public areas has always played and still plays an important socio-cultural role, based mainly on the direct relationship between merchant and buyer, enriched by its function as a catalyst for the urban space. Trade on public areas benefits from having as its location the market, where a wide range of products is located in relatively small space. The evolution of trade on public areas in Tuscany and, more generally, in Italy has made it a phenomenon quite special compared to that of other European countries [5]. In Florence, for example, the fondini, whose name refers to the particular position that these banks occupied at the bottom of the market, and the cassettai, which take their name from the container in the form of a box used to expose and sell the goods, represent a real tradition among the street vendors of the old town. On their desks are on sale local handicrafts, souvenirs, tourist guides, postcards and books of various kinds. These, together with other historical activities operating in the streets and the main markets and tourist groupings of the city, are recognized among the Historical and Traditional Florentine Economic Activities belonging to category C - "Historical Street Vendors".

The Progetto di documentazione dei chioschi, le edicole e i fiorai su area pubblica del Comune di Firenze concerned the structuring of a census system that would consider all the characteristics of these particular commercial activities, allow the control and updating of the data contained in the Regolamento per la disciplina dell'attività su area pubblica (2008)

Fig. 4. (left) Giorgio Vasari: the model for the Loggia del Mercato Nuovo, Palazzo Vecchio, room of Cosimo I, detail of the tondo with Cosimo and the artists at court; (right) Battista del Tasso: sketch of the aedicule of the Mercato Nuovo (GDSU 4106 Av) (by Battilotti 406 Av) (by Battilotti D pp. 75 and 77.
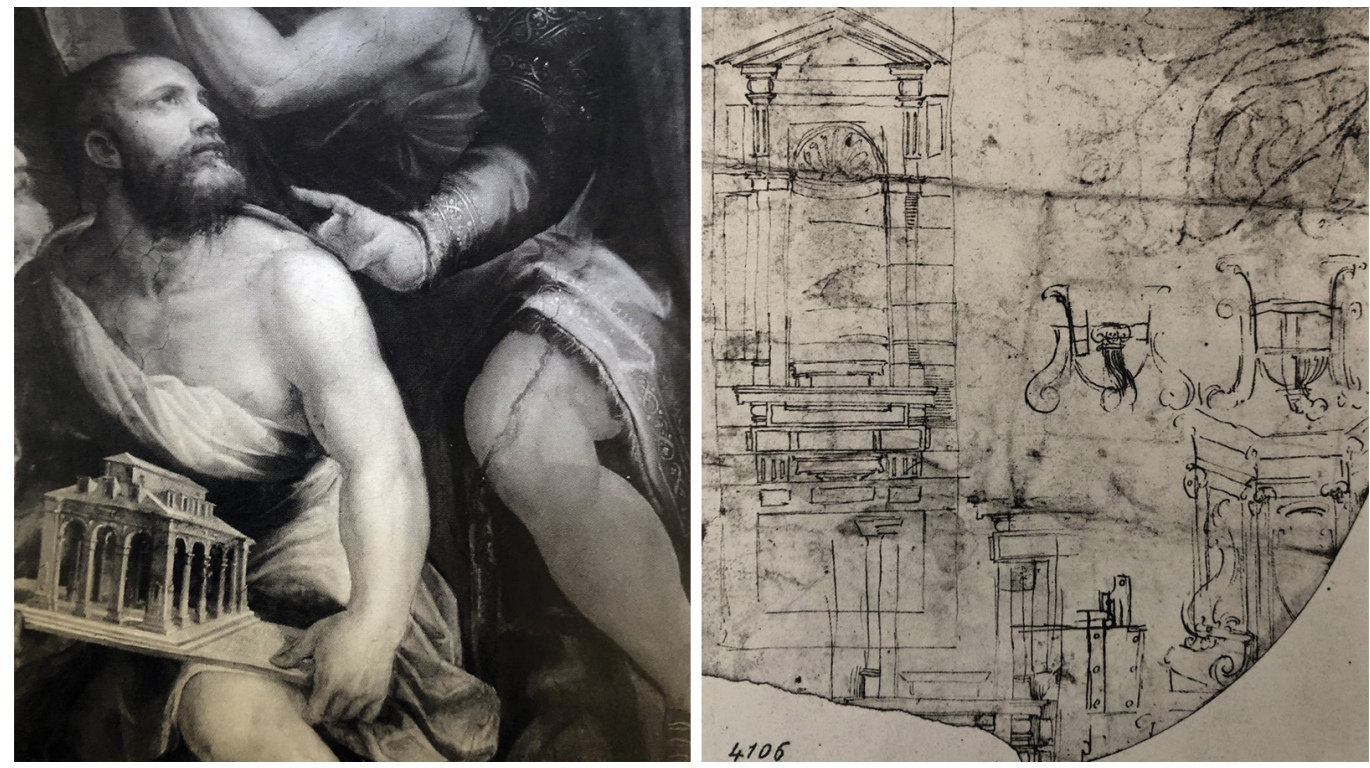
Fig. 5. Ponte Vecchio: longitudinal section

(students: Serena Liviani,

Claudia Logi, Giacomo

Morelli, Lorenzo Tognoni,

Gilda Mugnaini, Tommaso

Olianas).

Fig. 6. Ponte Vecchio: crosssection (students: Serena

Liviani, Claudia Logi, Giacomo Morelli).
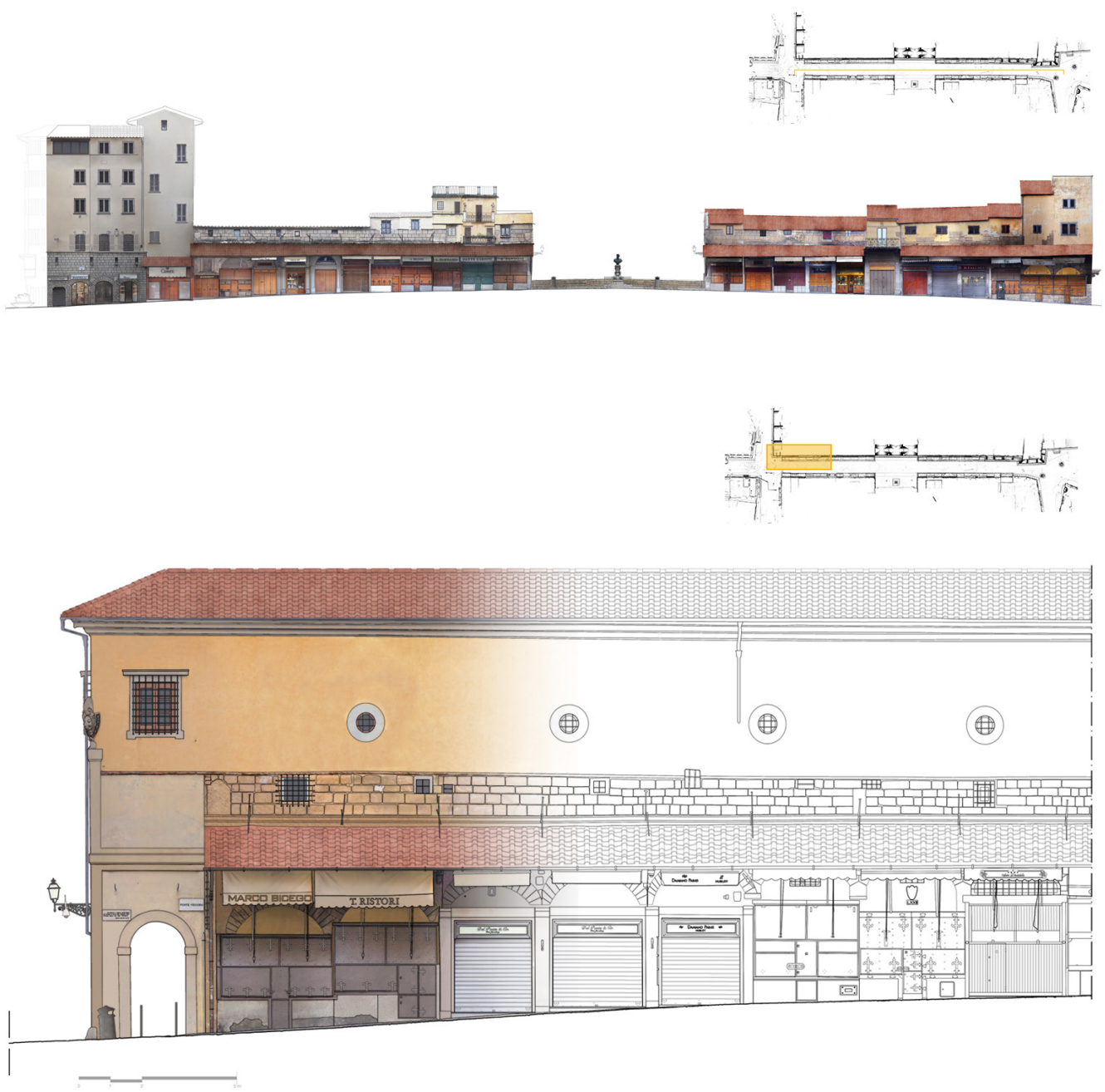

H
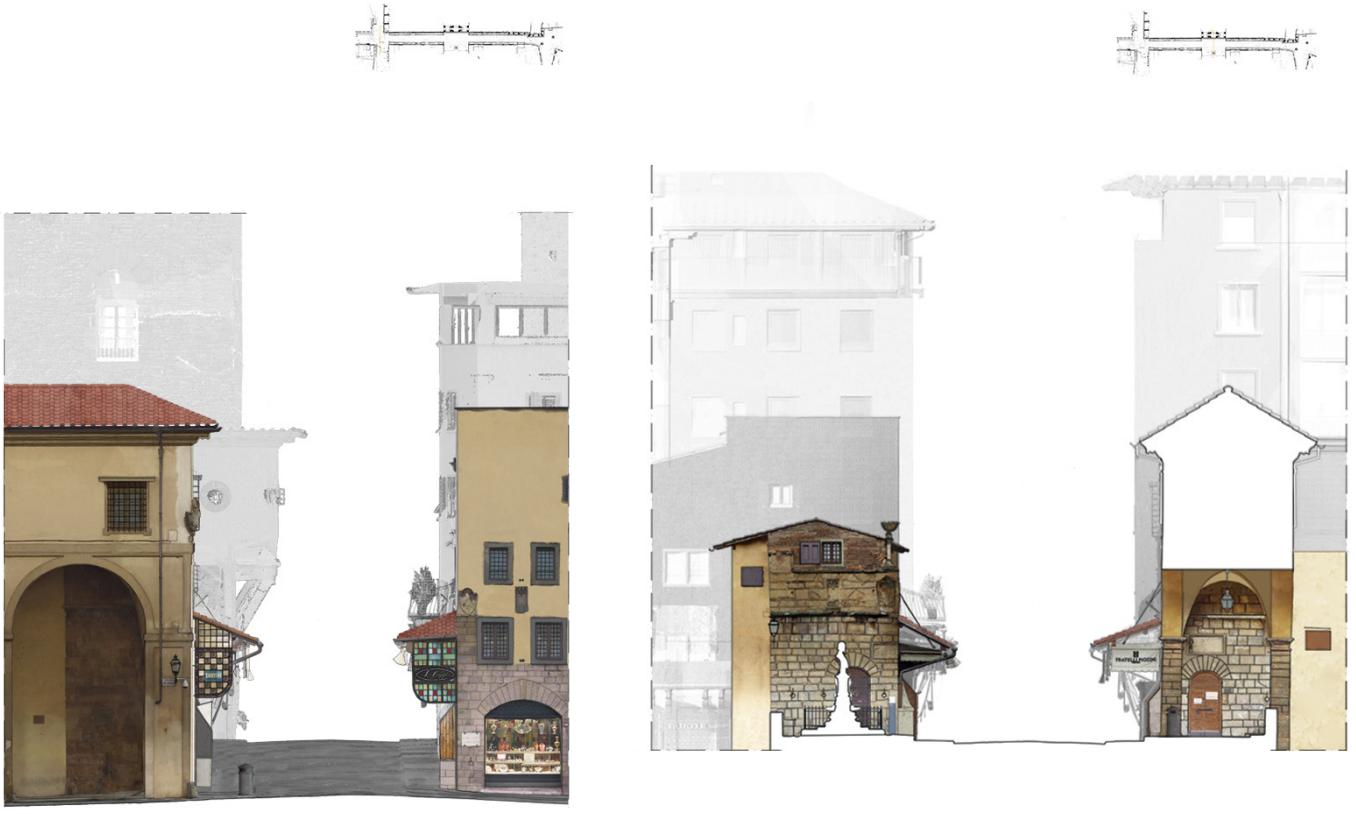

Fig. 7. Photos taken

during the photographic campaign for the Proget

chioschi, le edicole e

fiorai su area pubblica del Comune di Firenze. 
and the carrying out a photographic campaign for the documentation of the current status of the structures.

The datasheet has been structured on the basis of the information contained in the Regolamento per la disciplina dell'attività su area pubblica (2008) and has been subsequently enriched with elements that emerged during the census operations.

It can be divided into three parts:

A) General information: in the first section of the datasheet are provided the classification data, then all the information related to the property, the commercial area and the location in the city or the market. To precisely define the location the datasheet is filled with the coordinates, in this case, they assume particular importance because the location of these structures is not definable through a canonical address (it may be at the intersection of two roads, inside a garden).

In this part of the datasheet is also indicated if it is a mobile structure or a permanent one, and the type of product sold.

B) Description of the structure: the second section of the datasheet is dedicated to the description of the structure that hosts the commercial activity, it is described providing information on the dimension, the material and the color. It is analyzed from a qualitative point of view, assessing the state of conservation of the structure and the presence of elements of interest, such as some street art.

C) Relationship with the context: in the final section of the datasheet is analyzed the kiosk from the point of view of the relationship with the urban context, indicating for example the type of road in which it is located, but also the social one. Some of the kiosks have an important role for the people who live in the neighborhood, or they represent places of meeting and social aggregation or are located near buildings of high historical, artistic or cultural interest.

Fig. 8. Example of the datasheet made for the Progetto di documentazione dei chioschi le edicole i fiorai su area pubblica del Comune di Firenze.
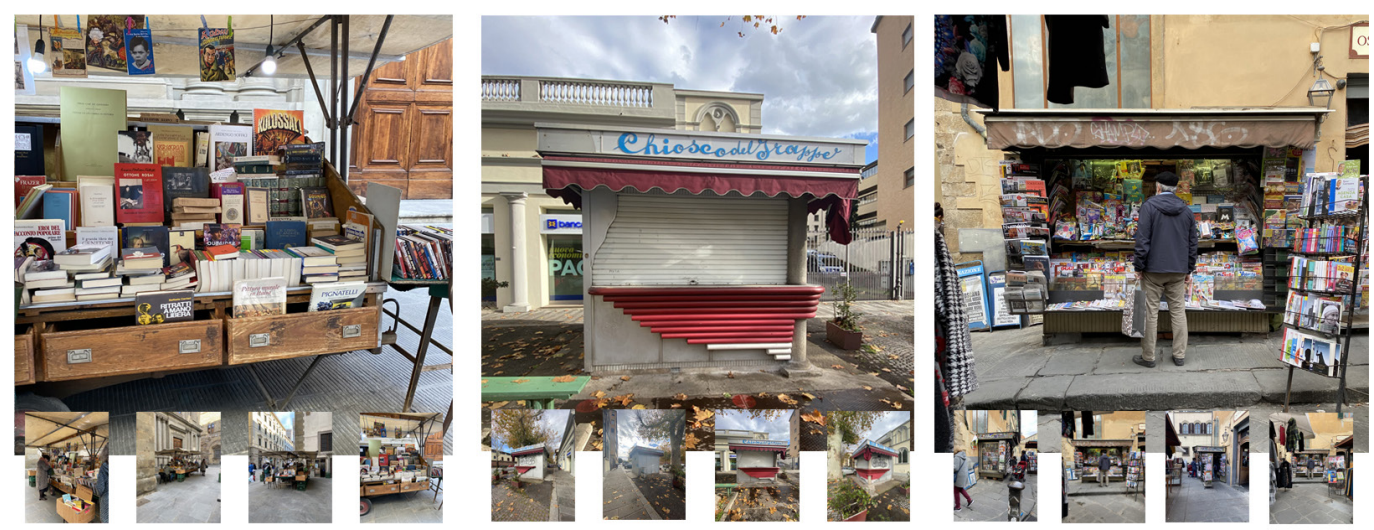

\section{Analysis of the results}

207 kiosks have been counted in the entire area of the Municipality of Florence, I 47 kiosks and 61 mobile structures. Most of them are located within the perimeter of the historic center and almost half are located within the commercial areas of Duomo and Piazza della Repubblica. The analysis of the result obtained showed that about a quarter of the activities listed in the lists annexed to the Regolamento per la disciplina dell'attivita su area pubblica (2008) are currently not present or not active. On the other hand, the analysis of merchandise genres has shown that the road trade maintains its traditional feature of information vehicle with the presence of newsstands, its social component with the kiosks dedicated to the selling of foodstuffs and they still represent the identity of the city distributing traditional 
Fig. 9. (left) Site plan of the kiosk, mobile structures and newsstands in th Municipality of Florence generated through the insertion of coordinates in the mapstr app; (right) analysis of the data obtained during the census activities of the Progetto di doucmentazione dei chioschi, le edicole e fiorai su area pubblica del Comune di Firenze:
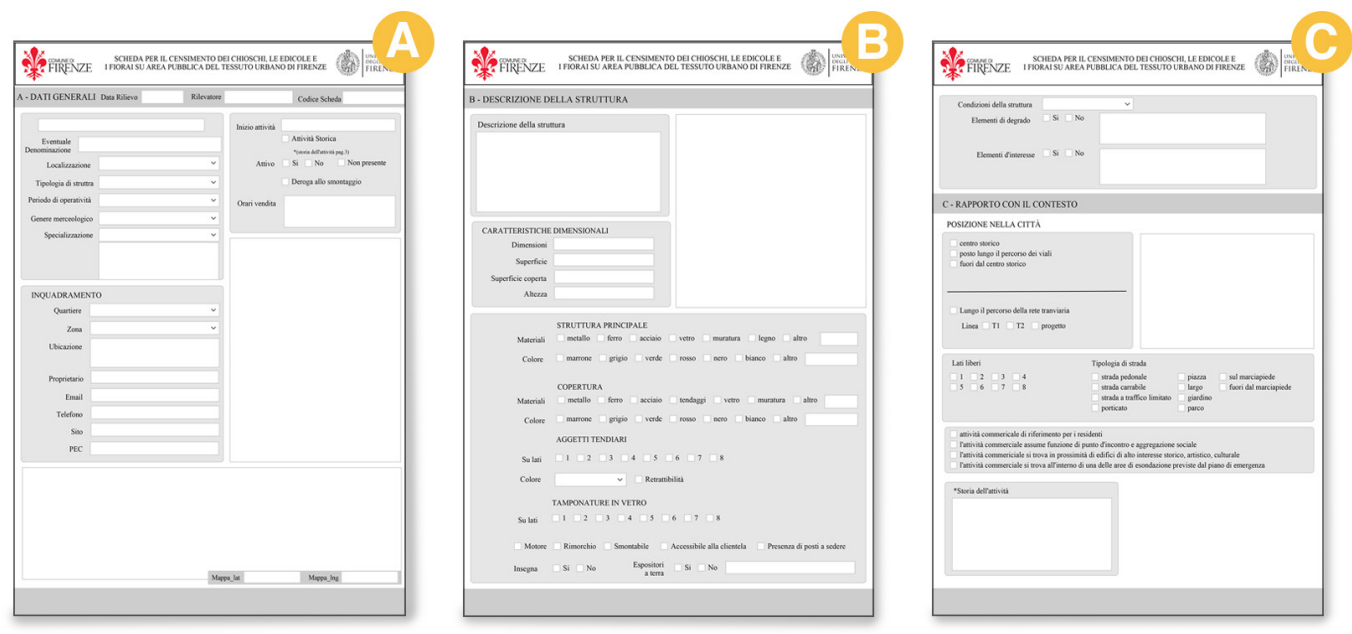

products such as lampredotto or local handicrafts. Commerce in its various forms is part of the urban structure of the city: it characterizes its appearance and contributes substantially to the vitality of the cities. This dynamism makes the commerce sector particularly sensitive to economic and social changes. The census and the documentation of historical shops of Florence, of the kiosks on public area of the City of Florence through the study of a sample case related to the survey of the urban axes that joins the Duomo to Ponte Vecchio have allowed obtaining an overall picture of the relations that exist not only between them and the urban context in which they are located but also to highlight the fundamental role that the street plays in defining these connections. The comparison with the starting data also showed how these activities are always in motion and therefore how the constant activity of documentation and monitoring is important the keep track of their transformation.

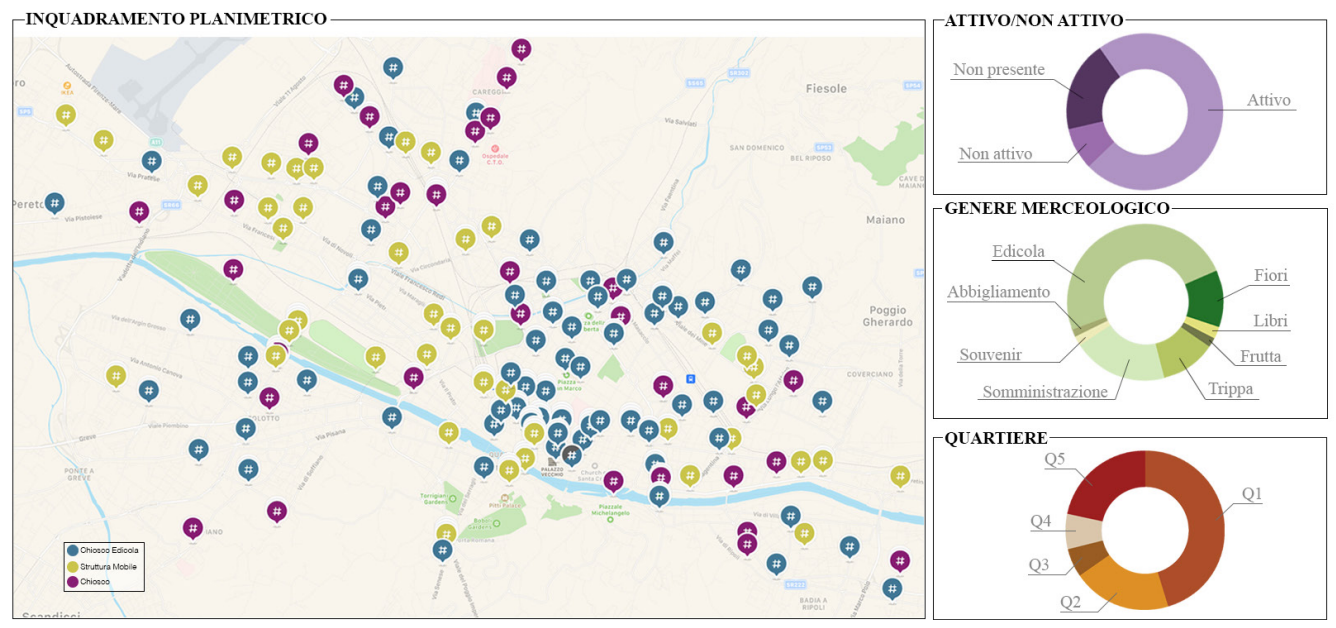




\section{Notes}

[I] Paragraphs I and 2 were written by Federico Cioli and paragraphs 3 and 4 were written by Roberta Ferretti.

[2] In the historical centers, there are still numerous signs, often protected by the local administration, belonging to activities closed for a long time. They are still mute testimonies of a commercial and productive past that, devoid of any informative apparatus, is configured mainly as an element of urban furniture.

[3] Current protection decree of the Ministero on the Caffè Paszkowski of 24/I0/1991.

[4] Emblematic is the case of the booksellers of Pontemoli who, during the 19th century, became real "information couriers" [Mazzocchi 200I, p. 28]

[5] Legge regionale n. 10 del 4 febbraio 2003 Norme per la disciplina del commercio su aree pubbliche.

\section{References}

Balzanetti Steiner G. (200 I). Firenze disegnata le strade da porta a porta nella successione delle mura urbane (Architettura e arte in Toscana 10). Firenze: Alinea.

Bertocci S., Cioli F. (20/8). La documentazione delle attività commerciali storiche del centro di Firenze. In R. Salerno (a cura di). Rappresentazione materiale/immateriale - Drawing as (in) tangible. 40 Convegno UID. Milano, I3- I5 settembre 20 I8, pp. 94 I-48. Roma: Gangemi Editore.

Bertocci S., Cioli F., Bordini E. (2018).Virtual models for the valorisation and promotion of the business heritage in the historic centre of Florence. In Disegnarecon:Advanced Technologies for Historical Cities Visualization, vol. I I, N. 2I, pp. 2.I -2. 19.

Betti S., Porto C. M. (2019). II commercio ambulante nella città contemporanea marchigiana. Analisi e prospettive di sviluppo. In AGEI - Geotema, n. 38, pp. I 8-29.

Bini M. (20।8). Le trasformazioni dell'immagine urbana: il sistema delle "botteghe". In P. Puma (a cura di). Firenze, la trasformazione del centro antico, pp. 62-72. Firenze: Edifir Edizioni Firenze.

Codeluppi V., Ferraresi M. (2007). La moda e la città (Studi economici e sociali Carocci 3). Roma: Carocci.

Fiorani E. (2005). I panorami del contemporaneo. Milano: Lupetti.

Job A., Laureati L., Ronchetta C. (1985). Botteghe e negozi a Torino /8/5-1925. Immagine del commercio fra architettura e decorazione. Torino: Allemandi.

Mazzocchi A. (200 I). I pellegrini del commercio - Il commercio ambulante: economia, cultura e società. Trento: II Margine.

Osello A., Coppo S., Coppo D. (2007). II Disegno di Luoghi e Mercati in Piemonte. Torino: Allemandi.

Pugnetti G. (1978). I Venditori ambulanti nel cammino della civiltà. Roma: Istituto Editoriale Regioni Italiane.

Romby G. C. (1989). Le forme e i luoghi del vendere e del comprare. In Proceedings of II negozio nel centro storico: nascita, vita, prospettive. Convegno nazionale, Lucca, Villa Bottini, I 5 gennaio 1989.

Senatore L.J. (20I3). La rappresentazione nello spazio commerciale. Storia, modelli, tendenze. Roma:Aracne.

\section{Authors}

Federico Cioli, Università di Firenze, federico.cioli@unifi.it

Roberta Ferretti, Università di Firenze, roberta.ferretti@unifi.it

To cite this chapter. Cioli Federico, Ferretti Roberta (2021). L'asse urbano dal Duomo a Ponte Vecchio a Firenze: sistemi di attività affini e commercio su suolo pubblico/The urban axis from Duomo to Ponte Vecchio in Florence: commercial activities systems and street trading. In Arena A., Arena M. Mediati D. Raffa P. (a cura di). Connettere. Un disegno per annodare e tessere Linguaggi Distanze Tecnologie. Atti del $42^{\circ}$ Convegno Internazionale dei Docenti delle Discipline della Rappresentazione/Connecting. Drawing for weaving relationship. Languages Distances Technologies. Proceedings of the $42^{\text {th }}$ International Conference of Representation Disciplines Teachers. Milano: FrancoAngeli, pp. I $489-1506$. 